\title{
Esetek és tanulmányok
}

\author{
Schubert András \\ Magyar Tudományos Akadémia, Könyvtár és Információs Központ, \\ Tudománypolitikai és Tudományelemzési Osztály, Budapest
}

\begin{abstract}
Az esettanulmányok és esetismertetések a tudományos szakirodalom fontos és egyre növekvő arányú részét képezik. A cikkben megvizsgáljuk ennek a publikációs kategóriának a részarányát és idézettségét az egyes szakterületeken. Általánosságban igazolódni látszik az a vélekedés, hogy a nagyszámú esettanulmány csökkentheti a folyóiratok impaktfaktorát. A tudománymetria saját szakirodalmában az esettanulmányok (legalábbis a cikkek címében feltüntetett módon) mérsékelt számban jelennek meg, viszont idézettségük lényegében megegyezik az egyéb publikációtípusokéval. Orv. Hetil., 2015, 156(46), 1871-1874.
\end{abstract}

Kulcsszavak: tudománymetria, esettanulmányok, esetismertetések

\section{Cases and studies}

Case studies and case reports form an important and ever growing part of scientific and scholarly literature. The paper deals with the share and citation rate of these publication types on different fields of research. In general, evidence seems to support the opinion that an excessive number of such publications may negatively influence the impact factor of the journal. In the literature of scientometrics, case studies (at least the presence of the term "case study" in the titles of the papers) have a moderate share, but their citation rate is practically equal to that of other publication types.

Keywords: scientometrics, case studies, case reports

Schubert, A. [Cases and studies]. Orv. Hetil., 2015, 156(46), 1871-1874.

(Beérkezett: 2015. augusztus 3.; elfogadva: 2015. szeptember 14.)

Az esettanulmány ( „case study”) a tudományos publikálás régi, jól bevált formája. „Hosszú ideje fontos helyet foglal el számos szakmában és tudományterületen a pszichológiától kezdve az antropológián, szociológián és politikatudományon keresztül a nevelés, a klinikai tudományok, a szociális munka és az adminisztrációtudomány területéig" (Wikipédia [1], hivatkozva a [2] és [3] irodalmakra). Az orvosi irodalomban az ilyen tanulmányok jelentős részét esetismertetés („case report”) címke alatt publikálják. Bár egyes szerzők megkísérelnek különbséget tenni a két publikációtípus között, általában arra hivatkozva, hogy az esettanulmánynak valamiféle elemzést is kell tartalmaznia a puszta esetismertetésen felül, általánosan elfogadottnak tekinthető a két fogalom egyenértéküsége [4]: mindkettő egyedi példák vagy nem reprezentatív kis minták alapján mutat be bizonyos jelenségeket.
Az utóbbi időkben az orvosi irodalomban két kapcsolódó publikációs forma, az esetsorozat („case series”) és a kohorszvizsgálat („cohort study”) mutat egyre növekvő népszerüséget. Mindkettő már egy következő lépcsőfokot jelent a kvantitatív vizsgálatok fejlettebb válfajai, a nem randomizált és randomizált kontrollált vizsgálatok irányában. Ezért célszerü elválasztani őket az esettanulmány/esetismertetés kategóriájától. Egymástól is megkülönböztetendőek [5]: a kohorszvizsgálatok longitudinális időbeli vizsgálatok, amelyek így az esetsorozatok egy speciális esetét alkotják. Mind a négy publikációtípus száma nagyon erôteljesen növekedik. Az 1. ábrán mutatjuk be az egyes típusok növekedési ütemét a megfelelő kategóriamegnevezéseknek a Thomson Reuters Web of Science Core Collection adatbázisában foglalt cikkek címeiben való előfordulása alapján. A 2000-es években az esettanulmányok számának kétszereződési ideje 6 év, a 


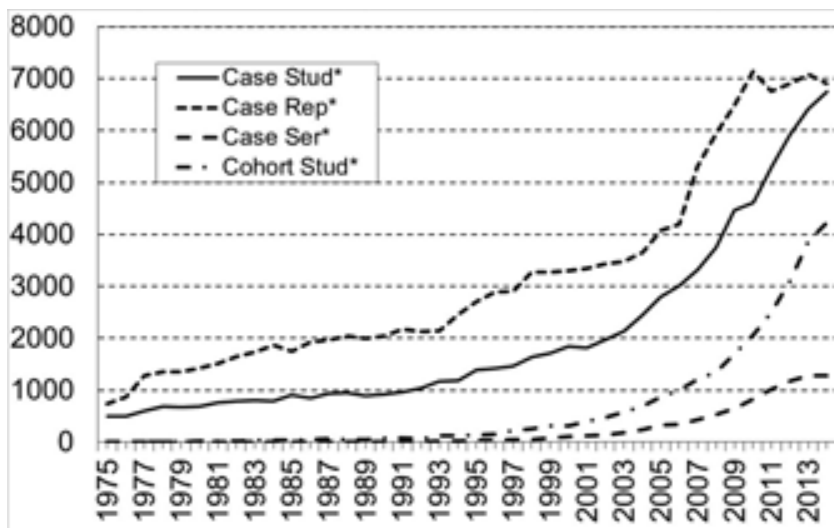

1. ábra

| Az „esettanulmány” és vele rokon szavak előfordulási gyakorisága a cikkek címeiben. Forrás: Thomson Reuters Web of Science Core Collection adatbázis

kohorszvizsgálatoké 4 év. Ez kivételesen gyors növekedést jelez. Az esetismertetések és az esetsorozatok görbéje a 2010-es évekre ellaposodni látszik.

A következókben a két alapesetre, az esettanulmányokra és az esetismertetésekre korlátozzuk figyelmünket. A vizsgált mintát a Thomson Reuters Web of Science Core Collection adatbázisban található 1975-2015 közötti cikkek közül azok alkotják, amelyek címében előfordultak a „case stud* " vagy „case rep*” szógyökök.

A címükben az „esettanulmány” szót tartalmazó cikkek döntő többsége ténylegesen esettanulmány. Meglepő módon éppen a legidézettebbek közül több azonban nem esettanulmány, hanem az esettanulmányokról szóló cikk, mondhatni „meta-esettanulmány” (mint például ez az írás). Mind közül a legidézettebb [6], amely 2015 júliusáig több mint 7000 idézetet kapott, azt a folyamatot írja le, amely az esettanulmányoktól az elméletig vezet a kérdésfeltevéstől egészen a kérdés lezárásáig. A cikk föként a társadalomtudományokkal - mindenekelőtt a menedzsmenttudománnyal - foglalkozik, de tanulságai bármely más tudományterületen is megszívlelhetők.

Egy másik erősen idézett „meta-esettanulmány” nagyon hasznos segítséget ad ahhoz, hogy jobban megértsük az esettanulmányoknak a tudományos megismerésben való szerepét. Flypbjerg [7] öt gyakori félreértést sorol fel az esettanulmányokkal kapcsolatban: a) az elméleti tudás értékesebb, mint a gyakorlati;

b) egyetlen esetből nem lehet általánosítani, ezért az egy esetre vonatkozó vizsgálatok nem járulnak hozzá a tudomány fejlődéséhez;

c) az esettanulmányok legfeljebb hipotézisek felállítására alkalmasak, a hipotézisek ellenőrzéséhez és elméletek felállításához más módszerekre van szükség;

d) az esettanulmányok az elfogadás irányában torzultak;

e) az esettanulmányok tanulságainak összessége nehézségekbe ütközik.

Ezeket a félreértéseket egyenként megmagyarázva és kiigazítva, a cikk arra a következtetésre jut, hogy ha egy kutatási területnek nincsenek gondosan megtervezett és végrehajtott esettanulmányai, akkor az a terület rendszerezett példaanyag nélküli, és egy példaanyag nélküli tudományterület hasznavehetetlen. A cikk fó fókuszában ismét a társadalomtudományok állnak, de a következtetések általános érvényünek mondhatók.

Az esettanulmányok/esetismertetések döntő többsége (több mint kétharmada) az orvosi és élettudományok területén jelent meg (2. ábra). A társadalom- és bölcsészettudományokat szorosan követik a környezeti tudományok, a múszaki tudományok (különösképpen a számítástudományok és az információtechnológia) és a földtudományok. A kémiában és a fizikában, valamint - érthetô módon - a matematikában lényegesen kevesebb az esettanulmány. (Vagy legalábbis ez nem jelenik meg a cikkek címében.)

A Wikipédiának [8] egy hivatkozással alá nem támasztott állítása szerint „sok nemzetközi folyóirat közöl ugyan esettanulmányokat, de korlátozza a nyomtatásban megjelentetett esettanulmányok számát, mert azok kedvezőtlen hatással vannak a folyóirat impaktfaktorára”. Néhány szórványos eredmény található ugyan az irodalomban $[9,10,11,12]$, az esettanulmányoknak az idézetekre vonatkozó hatása azonban rendszeresebb vizsgálatot érdemel. Ebból a célból a Web of Science 12 kategóriájában meghatároztunk néhány erre vonatkozó tudománymetriai mutatószámot. A kategóriákat úgy választottuk meg, hogy az orvostudományokat, a természettudományokat és a társadalomtudományokat is a

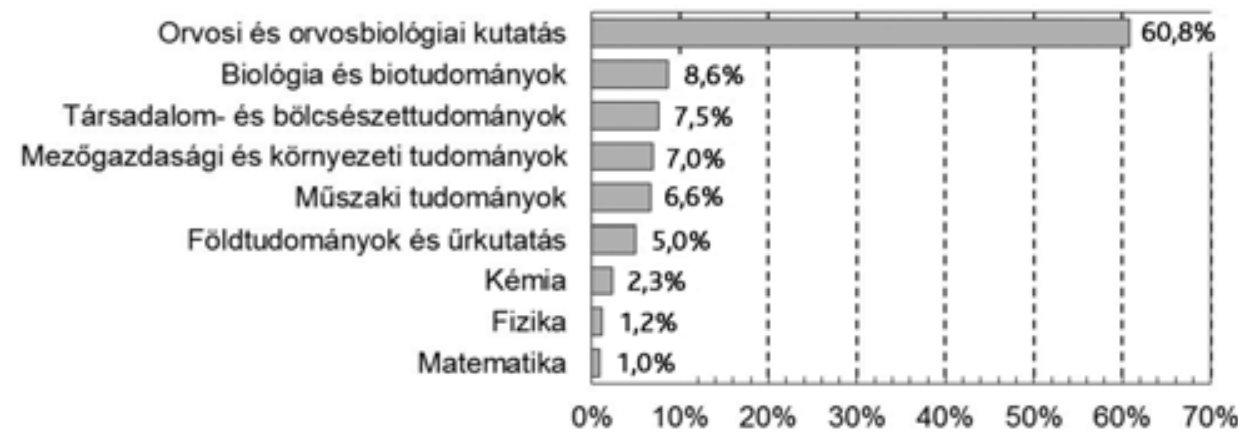

2. ábra $\quad$ Az esettanulmányok/esetismertetések megoszlása a szakterületek között. Forrás: Thomson Reuters Web of Science Core Collection adatbázis, 19742015 


\begin{tabular}{|c|c|c|c|c|c|c|}
\hline Kategória & Cikk, összesen & Cikk, ET/I & $\begin{array}{c}\text { Százalék, cikk, } \\
\text { ET/I }\end{array}$ & Idézettség, átlag & Idézettség, ET/I & $\begin{array}{c}\text { Százalék, } \\
\text { idézettség, ET/I }\end{array}$ \\
\hline \multicolumn{7}{|l|}{ Orvostudományok } \\
\hline Sebészet & 33701 & 2565 & $7,6 \%$ & 1,00 & 0,44 & $44 \%$ \\
\hline Klinikai neurológia & 25257 & 1995 & $7,9 \%$ & 1,02 & 0,48 & $47 \%$ \\
\hline Onkológia & 38514 & 1185 & $3,1 \%$ & 1,03 & 0,48 & $47 \%$ \\
\hline Belgyógyászat & 20465 & 1094 & $5,3 \%$ & 0,78 & 0,34 & $44 \%$ \\
\hline \multicolumn{7}{|l|}{ Természettudományok } \\
\hline Környezettudományok & 39557 & 1546 & $3,9 \%$ & 4,20 & 1,88 & $45 \%$ \\
\hline Földtudományok & 23623 & 928 & $3,9 \%$ & 3,29 & 1,42 & $43 \%$ \\
\hline Általános mérnöki tudomány & 14924 & 503 & $3,4 \%$ & 3,25 & 1,48 & $46 \%$ \\
\hline Ökológia & 16486 & 422 & $2,6 \%$ & 4,80 & 2,06 & $43 \%$ \\
\hline \multicolumn{7}{|l|}{ Társadalomtudományok } \\
\hline Neveléstan & 9654 & 388 & $4,0 \%$ & 1,53 & 0,58 & $38 \%$ \\
\hline Közgazdaságtan & 17305 & 286 & $1,7 \%$ & 2,09 & 0,87 & $42 \%$ \\
\hline Menedzsment & 7886 & 249 & $3,2 \%$ & 2,38 & 0,97 & $41 \%$ \\
\hline Könyvtár- és információtudomány & 3702 & 190 & $5,1 \%$ & 2,05 & 1,01 & $49 \%$ \\
\hline
\end{tabular}

legtöbb esettanulmányt közlő 4-4 kategória képviselje. Az eredményeket az 1 . táblázatban foglaljuk össze.

$\mathrm{Az}$ 1. táblázat rávilágít néhány figyelemreméltó sajátosságra. Egyes orvosi kategóriákban (például sebészet, klinikai neurológia) nemcsak az esettanulmányok/esetismertetések abszolút száma kiemelkedő, hanem a kategória összes publikációiból való százalékos részesedésük is. A természettudományokban ez a részesedés egyöntetűen $5 \%$ alatt marad, míg a társadalomtudományokban igen változatos a kép.

Másfelől, az esettanulmányok/esetismertetések idézettsége a kategóriák átlagához képest meglepően stabil. Minden esetben határozottan a kategóriaátlag fele alatt marad, ami a Wikipédia állítását igazolni látszik.

Az esettanulmányok/esetismertetések jelen vannak a tudománymetria irodalmában is. A Web of Science adatbázisban a $-\mathrm{TS}=$ (scientomet ${ }^{*} \mathrm{OR}$ informet ${ }^{*} \mathrm{OR}$ bibliomet* OR webomet* OR citation-anal*) OR SO $=($ scientometrics OR ,journal of informetrics" $)-$ keresőkérdésre kapott 11074 találat közül 213 (1,92\%) volt esettanulmány/esetismertetés. A 213 közül 125 (58,7\%) az utolsó hatéves időszakban (2010-2015) jelent meg. Erre az időszakra számítva az esettanulmányok/esetismertetések aránya az összes publikációból már 2,44\%. Ami igazán meglepő, az az, hogy ezeknek az esettanulmányoknak az idézettsége $(4,13)$ sokkal kevéssé marad el a terület átlagáétól $(4,71)$, mint az 1 . táblázat szakterületei esetében. A 87,7\%-os „teljesítmény" idézettségi szempontból sikeresnek mondható. A Scientometrics folyóiratban 2012-2013-ban közölt 16 esettanulmány 97,6\%-os aránnyal járul hozzá a folyóirat 2014. évi impaktfaktorához, vagyis ezek a többi publikációfajtával azonos mennyiségű idézetet vonzanak.

Az impaktfaktorral kapcsolatos megfontolások tehát nem indokolják az esettanulmányok közlésének korlátozását a Scientometrics-ben. A folyóirat szerkesztőjeként azonban egyetértek azzal, hogy egy szakterület vezető folyóiratainak a módszertani vagy szemléletbeli újdonságokat tartalmazó cikkeket kell preferálni a bevált módszerek rutinszerű alkalmazása helyett, még ha ez utóbbiak bizonyos érdeklődésre tartanak is számot. Az ilyen cikkek szerzőit ezért inkább arra szoktuk bátorítani, hogy kézirataikat országos vagy regionális témájú cikkek esetén a helyi folyóiratokba, egyes szakterületekre vonatkozó eredmények esetében az illető szakterület szakfolyóirataiba próbálják beküldeni.

Egyidejûleg próbáljuk elérni a folyóirat kiadójánál, hogy elindíthassuk a folyóiratnak egy online kiegészítését, amelyet kifejezetten az ilyen esettanulmányoknak szentelhetnénk. Próbálkozásaink sikere egyelőre még várat magára. Addig is, áthidaló megoldásként, még ez évben egy, az esettanulmányokat összegyưjitő külön füzetet tervezünk megjelentetni. A kísérlet sikerétől, illetve az online felület esetleges beindításától függően hasonló füzeteket a jövőben is megjelentethetünk.

Anyagi támogatás: A szerző köszöni az FP7-SSH-2013-2 \#613202 (IMPACT-EV) projekt támogatását.

A cikk végleges változatát a szerző elolvasta és jóváhagyta.

Érdekeltségek: A szerzőnek nincsenek érdekeltségei. 


\section{Irodalom}

[1] https://en.wikipedia.org/wiki/Case_study

[2] Mills, A. J., Durepos, G., Wiebe, E. (eds.): Encyclopedia of case study research. SAGE Publications, Thousand Oaks, California, 2010.

[3] Yin, R. K.: Case study research: Design and methods. 5th ed. SAGE Publications, California, 2014

[4] Crowe, S., Cresswell, K., Robertson, A., et al.: The case study approach. BMC Med. Res. Method, 2011, 11, 100.

[5] Dekkers, O. M., Egger, M., Altman, G., et al.: Distinguishing case series from cohort studies. Ann. Intern. Med., 2012, 156(1 Pt 1), 37-40.

[6] Eisenhardt, K. M.: Building theories from case study research. Acad. Manag. Rev., 1989, 14(4), 532-550.

[7] Flypbjerg, B.: Five misunderstandings about case-study research. Qualitat Inq., 2006, 12(2), 219-245

[8] https://en.wikipedia.org/wiki/Case_report
[9] Nieder, C., Pawinski, A., Dalhang, A.: Contribution of case reports to glioblastoma research: Systematic review and analysis of pattern of citation. Br. J. Neurosurg., 2012, 26(6), 809-812.

[10] Ruano-Ravina, A., Pérez-Ríos, M.: Regarding a case report: Rare diseases and bibliometric impact factor. J. Clin. Epidemiol., 2012, 65(8), 916-917.

[11] Nieder, C., Pawinski, A., Dalhang, A.: Contribution of case reports to brain metastases research: Systematic review and analysis of pattern of citation. PLoS ONE, 2012, 7(3), e34300.

[12] Mays, S.: The impact of case reports relative to other types of publication in palaeopathology. Int. J. Osteoarchaeol., 2010, $22(1), 81-85$.

\section{www.banila.hu}

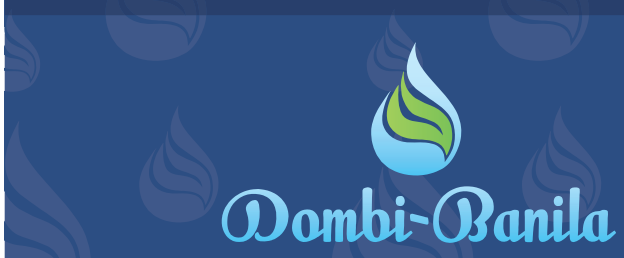

\section{$2013 \mathrm{Kft}$.}

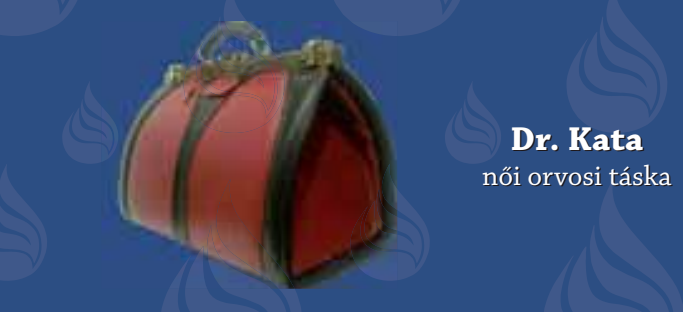

Termékeink a tradicionális orvosi táskakészítés eljárásával megegyező módon kerülnek gyártásra. A válogatott bőrök és a technológia eredménye egy kiváló minőségú, strapabíró táska. Kínálatunkból: orvosi táska, recepttartó, ampullatartó, női táska, utazótáska, pénztárcák, határidőnapló. Kérésére egyedi megrendelést vállalunk.

\section{Forgalmazó: dombine@banila.hu $+36-20 / 338-7270$}

Dombi-Banila $2013 \mathrm{Kft}$.
(Schubert András, e-mail: schuba@iif.hu)

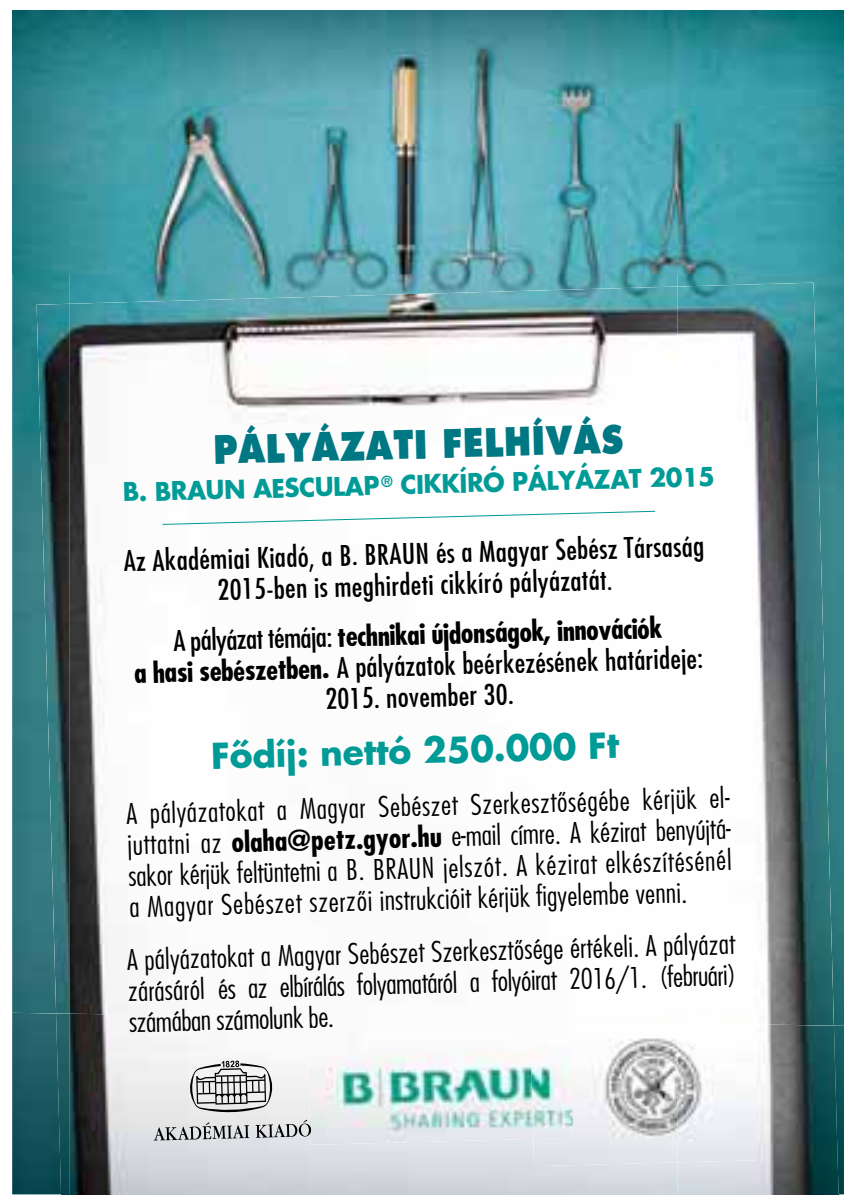

